
$\checkmark$ Research Square
Preprints are preliminary reports that have not undergone peer review.
They should not be considered conclusive, used to inform clinical practice, or referenced by the media as validated information.

\title{
2,4 -Dichlorophenoxyacetic Acid Induced Modulations in Immune System and Histopathological Alterations in Common Carp Cyprinus Carpio
}

\section{Amandeep Singh Dhot}

Guru Angad Dev Veterinary and Animal Sciences University

Admane Holeyappa Shanthanagouda ( $\sim$ shanthanagouda@gmail.com )

Guru Angad Dev Veterinary and Animal Sciences University https://orcid.org/0000-0002-9907-1129

Neelam Bansal

Guru Angad Dev Veterinary and Animal Sciences University

Naveenkumar BT

Guru Angad Dev Veterinary and Animal Sciences University

Anuj Tyagi

Guru Angad Dev Veterinary and Animal Sciences University

\section{Research Article}

Keywords: 2,4-D, Fish, Herbicide, Histomorphology, Immune response, Pesticide

Posted Date: January 17th, 2022

DOI: https://doi.org/10.21203/rs.3.rs-1229681/v1

License: (c) (1) This work is licensed under a Creative Commons Attribution 4.0 International License.

Read Full License 


\section{Abstract}

2,4-dichlorophenoxyacetic acid (2,4-D), the most commonly applied herbicide since 7 decades in different formulations. Its effects in the aquatic environment are not well documented, particularly on fishes. In the current study, Cyprinus carpio fingerlings were exposed to 2,4-D to understand the effect of different concentrations in two experiments including i) $\mathrm{LC}_{50}$ study for acute and ii) sub-lethal toxicity for physiological responses. In the acute toxicity, fish were exposed to $100,200,300,400$ and $500 \mathrm{mgL}^{-1} 2,4-$ $\mathrm{D}$ and resulted in $290 \mathrm{mgL}^{-1}$ as $\mathrm{LC}_{50}$ in $96 \mathrm{~h}$ exposure. During $96 \mathrm{~h}$, fish behaviour was monitored and mortality was recorded. In sub-lethal toxicity test, a separate batch of fish were exposed to $2.9 \mathrm{mg} / \mathrm{L}$ $\left(1 / 100^{\text {th }} \mathrm{LC}_{50}\right), 29 \mathrm{mg} / \mathrm{L}\left(1 / 10^{\text {th }} \mathrm{LC}_{50}\right)$ and $58 \mathrm{mg} / \mathrm{L}\left(1 / 5^{\text {th }}\right.$ of $\left.\mathrm{LC}_{50}\right)$ for 28 days, followed by immunological and histopathological responses were studied. The immunological responses indicated the adverse effect of 2,4-D on common carp by increasing the levels of superoxide dismutase (SOD) and catalase (CAT) responses indicating the DNA damage, in contrast the lysozyme activity and reactive oxygen species (ROS) declined. Meanwhile, histomorphological responses revealed the impairment in tissue microarchitecture such as proliferated nerve cells, clumped erythrocytes, tumour like structures in the brain, and prominent aneurysms and vasodilatations in gills, increased Bowman's space and melanomacrophages (MMCs) in the kidney, and vacuolizations in the liver. The results revealed that 2,4-D is immunotoxic and disparagingly alters tissue microarchitecture of fish.

\section{Introduction}

Pesticides play an imperative role in agriculture production, and herbicides constitute a largest group and receive special attention. Amongst, 2,4-dichlorophenoxyacetic acid (2,4-D) is the most widely applied in the last seven decades because of its affordability, wide spectrum and efficiency, and it is present in over 1,500 formulations in the markets (Tayeb et al., 2011; Islam et al., 2018). 2,4-D dissolves in water and also in other solvents making it ease for penetration in plants (Islam et al. 2018). It was introduced as a plant growth-regulator in 1942 and used in more than 100 countries. Primarily it is being applied in agriculture, forestry, home gardens to control aquatic vegetations (broad leaf) and to some extent as a growth regulator (WHO, 1984). Being a selective herbicide (Tayeb et al. 2011) it eliminates only dicots without affecting monocots and has the potential to alter protein synthesis and cell division in plants (Stevens and Breckenridge, 2001). According to the US Environmental Protection Agency (EPA), 2,4-D kills plants in three ways by modifiying the i) plasticity of plant cell walls, (b) protein synthesis and (c) enhancing the ethylene production.

The toxic effects of 2, 4-D to non-target organisms is studied extensively and revealed that it disrupts the metabolic activities in higher vertebrates such as rats. Specifically, 2,4-D is hepatotoxic (Tayeb et al. 2010), genotoxic (Abul Farah et al. 2003), neurotoxic (Bortolozzi et al. 2004; Freitas et al. 2019) and immunosuppressive (Pistl et al. 2003) in rats. Apart from these disruptions, studies have revealed that 2,4-D reduced growth rate, impaired reproduction, altered behaviour and appearance, and ultimately caused death (Wafa et al. 2011). 
Fish are highly sensitive to the contaminants, and are suitable bio-indicators of environmental contamination (Prusty et al. 2011). Various physiological responses are regularly used in fishes to know the effects of pollutants (Gimeno et al. 1995; Sancho et al. 2000). Among these responses, blood often exhibits pathological changes before fish exhibit any external symptoms due to contaminants, and frequently sampled without causing any disturbances to the animal or even death. Furthermore, the evaluation of biochemical and immunological characteristics in fish blood has become an important means of understanding possible mechanisms of toxicological impacts (Borges et al. 2007; Sudova et al. 2009). The activities of serum and or plasma enzymes have also been used as sensitive indicators of stress in fish exposed to diverse water pollutants (Kavitha et al. 2010). Among the several contaminants, studies on 2,4-D at immunological and histomorphological levels in fishes is scanty, and the present study investigated its impacts on ubiquitously available common carp, Cyprinus carpio at lethal and sublethal concentrations.

\section{Materials And Methods}

\section{Exposure experiment}

2,4-Dichlorophenoxyacetic acid (EC97\%) (2,4-D) of commercial grade was used for both lethal and sublethal exposures. Fish were exposed to different concentrations of 2,4-D including 100, 200, 300, 400 and $500 \mathrm{mgL}^{-1}$ to obtain the median lethal dose $\left(\mathrm{LC}_{50}\right)$. Both experiments were conducted in triplicates and each replicate contained 10 fish in it. During the experiment, fish were monitored regularly for their behavior and mortality. After obtaining $\mathrm{LC}_{50}$, a separate batch of fish were exposed for sub-lethal toxicity experiment. For sublethal toxicity test, fish were exposed to $2.9 \mathrm{mg} / \mathrm{L}\left(1 / 100 \mathrm{th}_{\mathrm{LC}} \mathrm{C}_{50}\right), 29 \mathrm{mg} / \mathrm{L}(1 / 10 \mathrm{th}$ $\left.\mathrm{LC}_{50}\right)$ and $58 \mathrm{mg} / \mathrm{L}\left(1 / 5\right.$ th of $\left.\mathrm{LC}_{50}\right)$ for 28 days, following which, immunological and histopathological responses were analysed. The water quality parameters such as temperature, $\mathrm{pH}, \mathrm{DO}$ and ammonia were regularly monitored. After termination of the exposure experiment, fish were utilized for immunological and tissue architecture studies.

The experiments were conducted as per the national and international guidelines for care and use of animals.

\section{Immunological parameters}

Immunological parameters such as superoxide dismutase (SOD), catalase (CAT), lysozyme activity and reactive oxygen species (ROS) were measured using protocols described earlier. Brifely, the blood samples were collected via the caudal vein near the caudal peduncle and the serum was separted by centrifuging at $5000 \mathrm{rpm}$ for $5 \mathrm{mins}$ and stored at $-20^{\circ} \mathrm{C}$. For SOD assay, reagents were used according to the protocol (Nishikimi et al. 1972) and the absorbance was recorded using UV/spectrophotometer (Lambda 25, Perki Elmer, Germany). The ROS was measured according to Anderson and Siwicki (1995). Briefly, Aeromonas hydrophila cells diluted in PBS were used along with $100 \mu \mathrm{L}$ of fish blood samples. While, lysozyme activity was measured following turbidimetric assay (Parry et al. 1965, Sankaran and 
Gurnani, 1972) with partial modification using PBS having pH 5.8 and young culture of Micrococcus lueteus. The reduction in the absorbance was measured at $450 \mathrm{~nm}$ at room temperature in ELISA microplate reader (Infinite M200 PRO, Tecan, Switzerland). While, catalase activity was measured according to Nicholls (1962) with phosphate buffer ( $\mathrm{pH} 7.0)$ and the abosorbance measured at $240 \mathrm{~nm}$ in a spectrophotometer thermostated at $25^{\circ} \mathrm{C}$.

\section{Histomorphology}

The microarchitecture of key tissues including the brain, gills, liver and kidney was performed using standard protocol Kong et al. (2008). Briefly, the tissue samples were preserved in $10 \%$ neutral buffered formaldehyde (Sigma Aldrich, CAS \#HT501128). Then processed in series of methanol and chloroform, and sectioned (4-6) $\mu \mathrm{m}$ using rotary microtome (Leica RM2125RT, Germany), and hematoxylin and eosin stained, then mounted (CAS \#130-12-2, Molychem Pvt. Ltd.). Images were photographed using NIKON 80i microscope.

\section{Statistical analyses}

The $\mathrm{LC}_{50}$ of 2, 4-D was caluculated using probit analyses with $95 \%$ confidence interval. One-way ANOVA was applied to understand the effect of 2,4-D on water quality, and immunological responses was performed using Statistical Package for the Social Sciences (SPSS v16.0). Following which, Duncan post-hoc test was applied for comparison purposes to determine the significant differences among the treatments and the significance was set at $\mathrm{P}<0.05$.

\section{Results And Discussion}

The $\mathrm{LC}_{50}$ of the 2,4 D was found to be $290 \mathrm{mg} \mathrm{L}^{-1}$ during the $96 \mathrm{~h}$ exposure having $95 \%$ confidence limits according to the acute toxicity results. The $\mathrm{LC}_{50}$ result of the current study is in contrast with that of Deivasigamani (2015) who reported $100 \mathrm{mgL}^{-1}$ for common carp and $34.64 \mu \mathrm{L}$ in guppy Poecilia vivipara (Viagario and Saboia-Morais 2014). This difference within the species could be due to the form of the pesticide used and also may be the environmental conditions. Further, a very low level $\mathrm{LC}_{50}$ of $2.86 \mathrm{mgL}^{-1}$ was recorded by Gaaied et al. (2020) in zebrafish embryos. Collectively, the differences observed may due to the difference in fish size, concentration of the pesticide, exposure intensity, susceptibility of the target animal which depends on the age, sex, health status and genetic variation (Fent 2003, 2004).

\section{Immunological responses}

The study showed increased activity of SOD and CAT with increase in 2,4-D concentrations (Table1). However, ROS and lysozyme activity decreased with 2,4-D exposure (Table 1). The high level of SOD and CAT activity in the exposed fish might have occurred due to the triggering of antioxidant enzymes for defense mechanism to overcome the negative effects of 2,4-D. While, the lysozyme activity was hindered due to the 2,4-D exposure, the activity of lysozyme decreased with increase in pesticides and its activity was significantly less compared to both positive and negative controls (Fig. 1). It is well accepted that 
fish phagocytes after activation are able to generate superoxide anion $\left(\mathrm{O}^{-}\right)$and its reactive derivatives (i.e. hydrogen peroxide and hydroxyl radicals) during the period of intense oxygen consumption, called the respiratory burst. These reactive oxygen species are toxic for bacterial pathogens (Paiva and Bozza, 2014) of fish. The results show that the activity of immune parameters in serum could be used as biomarkers for monitoring environmental stressors, and indicate that the activities of specific biomarkers in $C$. carpio are more sensitive to pesticides.

Table 1

Immunomodulation effect of sub-lethal concentrations of 2, 4-dichlorophenoxyacetic acid in C. carpio exposed for 28 days.

\begin{tabular}{|llll|}
\hline Treatments & ROS & SOD & CAT \\
\hline T1 & $1.08 \pm 0.12^{\mathrm{a}}$ & $2.48 \pm 0.24^{\mathrm{a}}$ & $2.12 \pm 0.17^{\mathrm{a}}$ \\
\hline T2 & $0.81 \pm 0.10^{\mathrm{b}}$ & $3.51 \pm 0.49^{\mathrm{b}}$ & $3.82 \pm 0.45^{\mathrm{b}}$ \\
\hline T3 & $0.79 \pm 0.09^{\mathrm{b}}$ & $3.97 \pm 0.60^{\mathrm{C}}$ & $4.26 \pm 0.56^{\mathrm{c}}$ \\
\hline T4 & $0.74 \pm 0.11^{\mathrm{b}}$ & $4.21 \pm 0.61^{\mathrm{d}}$ & $5.11 \pm 0.81^{\mathrm{d}}$ \\
\hline
\end{tabular}

Amongst the several immune parameters, lysozyme is one of the important defense molecules that is altered due to pesticides (Saurabh and Sahoo, 2008). Previously, a study revealed a significantly decreased lysozyme activity in plasma, liver, kidney and spleen in great sturgeon Huso huso (KhoshbavarRostami et al. 2006) exposed to diazonin. Similarly, it has been reported that chlorpyrifos elicited lysozyme attenuation in plasma and spleen of common carp (C. carpio) exposed acutely to $75 \mu \mathrm{g} / \mathrm{L}$ (Li et al. 2013). In contrast, 2.0 and $4.0 \mathrm{mg} / \mathrm{L}$ diazinon in grass carp Ctenopharyngodon idella significantly induced lysozyme activity (Soltani and Pourgholam, 2007) and chlorpyrifos $(0.102$ and $0.255 \mathrm{mg} / \mathrm{L}$ ) in Nile tilapia Oreochromis niloticus (El-Bouhy et al. 2014). It was also reported that exposure of Nile tilapia O. niloticus to chlorpyrifos $(0.102$ and $0.255 \mathrm{mg} / \mathrm{L})$ provoked an increase in the activity of lysozyme in the plasma of these organisms; however, at a lower concentration $(0.051 \mathrm{mg} / \mathrm{mL})$ the pesticide did not cause any effect on lysozyme (Zahran et al. 2018). In turn, disruption of lysozyme which has antibiotic properties originates in leucocytes that possess a broader functions (Demers and Bayne, 1997) has been frequently utilized as an indicator of non-specific immune functions, which combats primary infections in fish would deleteriously get affected due to pesticides in fish (Saurabh and Sahoo, 2008). It may be challenging to demarcate the causes for immunological responses caused by various contaminants, perhaps it is possible to consider these as suitable biomarkers for quick scrutiny of pesticides, using live fish.

\section{Histomorphology}

The current study extensively focussed on histopathology of selected tissues, since micro-architecture of the organs provides detailed information about the screeening of environmental pollutants using target tissues. The study observed a disparaging alterations in the tissues at sub-lethal levels and the responses 
were dose dependent, however no differences observed between control and environmental concentration $(29 \mu \mathrm{g} / \mathrm{L})$ of $2,4-\mathrm{D}$, hence histology pictures for environmental concentration is not provided for any of the tissues studied.

2,4-D is a synthetic auxin (a plant hormone), which is absorbed by the leaves of plants. Upon its application, plants respond with uncontrolled and unsustained growth, which ulitimately kills plant (Clark and Pazdernik, 2016). Similarly, in the current study, 2,4-D might have increased the cell numbers and formed tumours at high concentrations in fish tissues with exposure. And it is reported that nervous system is one of the targets for 2,4-D and effects were found relating to degeneration of nerve motor function, lethargic and behavioural changes (Bortolozzi et al. 2001; De Morro et al. 1993) in rats and chick embryos. In zebrafish embryos, a significant loss of nerve signals, reduced axon projections to the tectum, thin and truncated neuron axons of the motor regions were observed (DeMarco et al. 2021).

In the histological investigations, tegmentum area of the brain of unexposed fish showed a well organized nerve fibres and uniformly scattered nerve granules and clearly visible erythrocytes (Fig. 2A). While, fish exposed to $2.9 \mathrm{mg} / \mathrm{L}$ 2,4-D revealed increased intensity of dark granules, and nerve fibres in bundles (Fig. 2B). However, at $29 \mathrm{mg} / \mathrm{L}$ 2,4-D, the quantity of nerve fibres decreased and the nerve granules were prominent, along with pigments. In some regions of the tegmentum, pyknosis of granules were observed along with clumping of erythrocyte (Fig. 2C). Whereas, high concentration exhibited severely intensified (dense) granules and reduced nerve fibres (Fig. 2D). It was also noticed that the cilia at the borders of the tegmentum was severely affected as the concentration of the herbicide increased. The increase in granules reflects the basic property of 2,4-D where it enhances growth of plants through increase in cell numbers, hence in fish also it might have proliferated cells leading to tumour formation. However, in zebrafish significantly increased cell death, damaged growth of motor neurons and found less teratogenic. These differences could be due to either species sensitivity and or age of the fish. The cell death observed in zebrafish embryos could be to the development of the animal where cell proliferation was inhibited (Ton et al. 2006), however the precie mechanism for such differences need to investigated.

Pineal gland, an endocrine gland that plays an imperative role in melatonin production, and also functions in photosensitivity (Dodt, 1963). A well organized pinealocytes and astrocytes were observed in pineal gland, and these cells possessed proper shapes along with uniformly distributed erythrocytes in unexposed fish (Fig. 2E). While with 2,4-D exposures, erythrocyte numbers increased with abnormal shape along with big sized blood vessels, cell necrosis and size of the pinealocytes also increased (Fig. 2F\&G). Whreas at highest concentrations, vacuolization was severe and nerve fibres were disrupted disparagingly (Fig. 2H). The alterations observed would affect the melatonin secretion, followed by hypothalamic-pituitary-thyroid axis driven pigmentations, perhaps this could be used as a potential biomarker. Besides, it might affect the regulation of other physiological rhythms including translating photoperiodic stimuli into function (Walton et al. 2011; Zheng et al. 2021), since it plays an important role in regulation of circadian rhythms. It is also proven that any environmental stressor that alters the function of pineal gland would lead to jeopardy on the well-being of vertebrates including fish (Sanchez- 
Vazquez et al. 2019). The perturbed homeostasis of the melatonin would ultimately result in altered circadian rhythms which might hinder the fitness of the fish in terms of survival, growth and reproduction, (Zheng et al. 2021) and consequently biased sex ratio.

The tectum of the brain revealed a clearly visible mononuclear cells along with uniformly distributed nerve fibres in unexposed fish (Fig. 2I). While with increased concentrations, the fibrous dendrites, necrosis, vacuolization were initiated and the erythrocyte numbers increased (Fig. 2J\&K). However, at highest concentration, multi-nucleated cells and severe vacuolization was prominent (Fig. 2L). Since tectum is a sensory and primarily visual in function (Northmore, 2011), damage in it by herbicide exposure might affect locating food and may lead to loss of prey and predator relationship. Similar alterations were also observed by Mishra and Devi (2014) in Channa sp exposed to chlorpyrifos. The alterations observed in the optic tectum reflects the motor coordination in animals (Marks and Berg, 1999; Kermer et al. 2004). The vacuolization in the tectum due to 2,4-D in the current study are similar to alterations in the retina and lens of fish contaminated by detergent (Huang and Wang, 1995). Collectively, the changes observed might influence the normal function of the brain because it plays an important role for visualization (Roy et al. 2006). The 2,4-D exposure induced cell manifestation, and may drastically affect fish behavior. The results of the study opine that 2,4-D is immunotoxic and neurotoxic and it may influence the visual and sensory functions of fish (Mishra ands Devi, 2014).

While, thalamus of the brain in unexposed fish revealed that the nerve fibres were very clearly distributed and erythrocytes were well organized with proper shapes (Fig. 2M). Whereas, fish exposed to highest concentration of 2,4-D exhibited thick blood vessels, clumping of blood cells and nerve tumours (Fig. 2N). The abnormal proliferation of cells might have led to the formation of tumor in the brain due to 2,4-D. According to our knowledge, this is the first report which identified tumor formations in fish the brain due to herbicide and it needs further studies to understand the precise mechanisms.

The study presented a well organised primary and secondary lamellae along with uniformly distributed chondrocytes in control group (Fig. 3A). Whereas, fish exposed to 2.9 and $29 \mathrm{mg} / \mathrm{L}$ 2,4-D exhibited a minute telangiectasia, increased erythrocytes, necrosis, leukocyte infiltration, fused secondary lamellae, vasodilatations and decreased chondrocyte size (Fig. 3B\&C). At highest concentration, numerous aneurysms, congregated erythrocytes in aneurysms, and reduced chondrocytes in primary lamellae were prominent (Fig. 3D). Similar observations were also made in P. vivipara exposed to 2,4-D (Vigario and Saboia-Morais, 2014). The histopathological alterations observed for pesticide exposures in the earlier investigations have revealed that the gills are the primary routes for entry of several contaminants, and possess large suface area having direct contact with water (Simonato et al. 2008; Abdel-Moneim et al. 2012; Baskar, 2014). The numerous aneurysms recorded at the higher concentrations of 2,4-D exposure could be due to the rupture of pillar cells associated with increased blood flow (Camargo and Martinez, 2007; Paulino et al. 2014) which might have caused by the stress that is induced by the pesticide exposure. The alterations observed in gills might be because of polarity of 2,4-D and it can contact and interact easily with the epithelial cells (Vigario and Saboia-Morais, 2014). As per the current and earlier 
studies, histopathology of gills is one of the excellent biomarkers for environmental impact assessment and provide relevent information on the health status (Strzyżewska-Worotyńska et al. 2017).

Concurrently, the study recorded a uniformly distributed proximal convoluted tubules (PCT) and distal convoluted tubules (DCT) in unexposed fish (Fig. 4A). Whereas with 2,4-D exposures, lumen in PCT was noticeable, and damage of hematopoietic tissue was evident (Fig. 4B). With increased concentration (29 $\mathrm{mg} / \mathrm{L}$ ), Bowman's space increased, minute tumour nodules and melanomacrophages (MMCs) were prominent (Fig. 4C). At highest concentration, fluid accumulations (exudates) were commonly found, severe damage of kidney tissue through the formation of tumour was more prominent along with huge vacuolisations (Fig. 4D). Similar alterations were also observed in Clarias gariepinus exposed to cypermethrin (Velmurugan et al. 2009) and Piaractus mesopotamicus exposed to trichlorofon (Mataqueiro et al. 2009). The yellowish to black MMCs observed in hematopoetic tissues of kidney and liver indicated the development of chronic inflamatory lesions (Agius and Roberts, 2003) or stress (Peters and Schwarzer, 1985) are a consequences of 2,4-D exposure. These alterations implicate the deterioration of the renal tubules, glomuruli and tumour formation, and the intensity of damage was increased with increased concentrations and similar changes were also observed in rats exposed to malathion (Al-Attar, 2010). The disparaging alterations observed in kidney in various investigations reveal that these changes might take place to perform the sequestration of the pesticides for their degradation to reduce the toxicity of the contaminants (Agius and Roberts, 2003), by compromising their micro-architecture.

Liver, an organ for metabolism, detoxification and accumulation of toxic substances. In the current investigation, uniformly distributed hepatocytes and Kupffer cells were observed in unexposed fish (Fig. 5A). However, at environmental concentration, slight vacuolization was initiated to appear and with a few anucleated hepatocytes (figure not shown). While at sub-lethal concentrations, yellowish to black MMCs were noticed (not shown in figure), pancreas appeared thickening and vacuolization was more prominent with pyknosis of hepatocytes (Fig. 5C\&D). These responses are in agreement with the Vigario and Saboia-Morais (2014) in P. vivipara exposed to 2, 4-D. In both studies the responses were dose dependent and severity of effects increased with increase in 2,4-D concentration. The vacuolization observed at higher concentration indicate the toxic effect of 2,4-D and this might lead to tumour formation through spongiosis (Hinton and Lauren, 1990; Ortiz et al. 2003). The disaapearance of nuclei or micronuclei observed in the exposed fish might be an indication of genotoxicity of 2,4-D, and perhaps this would be adpoted as genotoxic assessment tool as it is a simple and short term assay which helps monitoring the water quality (Grisolia, 2002).

In summary, the study showed 2,4-D as an immunotoxic, and perturbed multiple tissues investigated. Further studies are warranted to understand its precise neurotoxic effects. The histo-architecture witnessed that 2,4-D can cause tumours in multiple tissues through cell proliferation. However, future studies are warranted to know the molecular insights of herbicides impact either in fish or any other aquatic animals.

\section{Declarations}




\section{Competing interests}

All authors have no competing interests to declare.

\section{Funding}

This research did not receive any specific grant from funding agencies in the public, commercial or notfor-profit sectors.

\section{Acknowledgement}

The authors express their gratitude to the Dean, College of Fisheries, Guru Angad Dev Veterinary and Animal Sciences University (GADVASU), Ludhiana, Punjab, India, for providing facilities to perform the research. Authors are also gratitude to Head, Departement of Veterinary Anatomy, GADVASU for facilitating the microscope facility.

\section{References}

1. Abdel-Moneim AM, Al-Kahtani MA, Elmenshawy OM (2012) Histopathological biomarkers in gills and liver of Oreochromis niloticus from polluted wetland environments. Saudi Arabia, Chemosphere 88:1028-1035

2. Abul Farah M, Ateeq B, Ali N, Ahmad M W (2003) Evaluation of genotoxicity of PCP and 2,4-D by micronucleus test on freshwater fish Channa punctatus. Ecotoxicol Environ Saf 54:25-29

3. Agius C, Roberts RJ (2003) Melano-macrophage centers and their role in fish pathology. J Fish Dis 26:499-509

4. Al-Attar AM (2010) Physiological and histopathological investigations on the effects of a-lipoic acid in rats exposed to malathion. Journal of Biomedicine and biotechnology

5. Anderson DP, SiwickiA K (1995) Basic haematology and serology for fish health programs. Fish Health Section, Asian Fisheries Society, Manila, Philippines, pp. 185-202

6. Baskar T (2014) Impact of nitrite toxicity on histopathological profile to freshwater fish, Cirrhinusmrigala. The International Journal of Engineering and Science 3(4):42-47

7. Borges A, Scotti LV, Siqueira DR, Zanini R, Do Amaral F, Jurinitz DF, Wassermarin GF (2007) Changes in hematological and serum biochemical values in jundiaRhamdiaquelen due to sub-lethal toxicity of cypermethrin. Chemosphere 69:920-926

8. Bortolozzi AA, De Duffard E, Duffard AM, Antonelli RO MC (2004) Effects of 2,4-

dichlorophenoxyacetic acid exposure on dopamine D2-like receptors in rat brain. Neurotoxicol Teratol 26:599-605

9. Bortolozzi A, De Duffard AM, Dajas F, Duffard R, Silveira R (2001) Intracerebral Administration of 2,4Diclorophenoxyacetic Acid Induces Behavioral and Neurochemical Alterations in the Rat Brain. NeuroToxicology. 22 (2): 221-232 
10. Camargo MMP, Martinez CBR (2007) Histopathology of gills, kidney and liver of a neotropical fish caged in anurban stream. Neotropical Ichthyology 5(3):327-336

11. Clark DP, Pazdernik NJ (2016) Transgenic plants and plant biotechnology, chapter 15. Biotechnology (Second Edition). Applying the Genetic Revolution. 461-492

12. DeMarco E, Tesmer AL, Hech B, Kawakami K, Robles E (2021) Pyramidal neurons of the zebrafish tectum receive highly convergent input from torus longitudinalis. Front Neuroanat 15:636683

13. De Morro GM, Duffard R, De Duffard AM (1993) Neurotoxicity of 2,4-dichlorophenoxyacetic butyl ester in chick embryos. Neurochem Res 18:353-359

14. Demers NE, Bayne CJ (1997) The immediate effects of stress on hormones and plasma lysozyme in rainbow trout. Developmental and Comparative Immunology 21:363-373

15. Deivasigamani S (2015) Effect of herbicides on fish and histological evaluation of common carp (Cyprinus carpio)

16. Dodt E (1963) Potosensitivity of the pineal organ in the teleost, Salmo irideus (Gibbons). Experientia 19:642-643

17. El-Bouhy ZM, El- Nobi G, Reda RM, Ibrahim RE (2014) Effect of insecticide "Chlorpyrifos" on immune response of Oreochromis niloticus. Zagazig Veterinary Journal 44:3

18. Fent K (2003) Ecotoxicological problems associated with contaminated sites (review). Toxicol Lett 140(141):353-365

19. Fent K (2004) Ecotoxioclogical effects at contaminated sites. Toxicology 205:223-240

20. Freitas LM, de Assis Valadares LP, Camozzi MGM, de Oliveira PG, Ferreira Machado MR, Lima FC (2019) Animal models in the neurotoxicology of 2,4-D. Hum Exp Toxicol 38(10):1178-1182

21. Gaaied S, Oliveira M, Domingues I, Banni M (2020) 2, 4-Dichlorophenoxyacetic acid herbicide effects on zebrafish larvae: development, neurotransmission and behavior as sensitive endpoints. Environ Sci Pollut Res 27(4):3686-3696

22. Gimeno L, Ferrando MD, Sanchez S, Gimeno LO, Andreu E (1995) Pesticide effects on eel metabolism. Ecotoxicol Environ Saf 31:153-157

23. Grisolia CK 2002.A comparison between mouse and fish micronucleus test using cyclophosphamide, mitomycin $C$ and various pesticides. Mutat.Res.518:145-150

24. Hinton DE, Laurén DJ (1990) Integrative histopathological approaches to detecting effects of environmental stressors on fish, p.51-66. In: Adams S.M. (Ed.), Biological Indicators of Stress in fish. Bethesda:8th American Fishery Society Symposium, Bethesda

25. Huang BQ, Wang DY (1995) Corneal damage in young tiger perch (Terapon jarbua) exposed to the surfactant linear alkylbenzene sulfonate (LAS). Zool Stud 34:41-46

26. Islam F, Wang J, Farooq MA, Khan MSS, Xu L, Zhu J, Zhao M, Munos S, Li QX, Zhou W (2018) Potential impact of the herbicide 2,4-dichlorophenoxyacetic acid on human and ecosystems.Environment International. 111:332-351 
27. Kavitha C, Malarvizhi A, Senthil Kumaran S, Ramesh M (2010) Toxicological effects of arsenate exposure on hematological, biochemical and liver transaminases activity in an Indian major carp, Catla catla. Food Chem Toxicol 48:2848-2854

28. Khoshbavar-Rostami HA, Soltani M, Hassan HMD (2006) Immune response of great sturgeon (Husohuso) subjected to long-term exposure to sublethal concentration of the organo- phosphate. diazinon Aquaculture 256(1-4):88-94

29. Kermer P, Liman J, Weishaupt JH, Bahr M (2004) Neuronal apoptosis in neurodegenerative diseases: from basic research to clinical application. Neurodegen Dis 1:9-19

30. Kong RYC, Giesy JP, Wu RSS, Chen EXH, Chiang MWL, Lim BB, Yuen BBH, Yip BWP, Mok HOL, Au DWT (2008) Development of a marine fish model for studying in vivo molecular responses in ecotoxicology. Aquat Toxicol 86:131-141

31. Li X, Liu L, Zhang Y, Fang Q, Li Y (2013) Toxiceffectsofchlorpyrifos on lysozyme activities, the contents of complement C3 and IgM, and IgM and complement C3 expressions in common carp (. CyprinuscarpioL) Chemosphere 93(2):428-433

32. Marks N, Berg MJ (1999) Recent advances on neuronal caspases in development and neurodegeneration. Neurochem 35:195-220

33. Mataqueiro MI, Satiko Okada Nakaghi L, De Souza JP, Da Cruz C, De Oliveira GH, Urbinati EC (2009) Histopathological changes in the gill, liver and kidney of pacu (Piaractus mesopotamicus, Holmberg, 1887) exposed to various concentrations of trichlorfon. J Appl Ichthyol 25:124-127

34. Mishra A, Devi Y (2014) Histopathological alterations in the brain (optic tectum) of the fresh water teleost Channa punctatus in response to acute and subchronic exposure to the pesticide Chlorpyrifos. Acta Histochem 116:176-181

35. Nicholls $P$ (1962) The reaction between aminotriazole and catalase. Biochimica et Biophysica Acta 59(2):21, 414-420

36. Nishikimi M, Appaji N, Yagi K (1972) The occurrence of superoxide anion in the reaction of reduced phenazinemethosulfate and molecular oxygen. Biochem Biophys Res Commun 46(2):849-854

37. Northmore DPM (2011) Optic tectum. In: Farrell A (ed) Encyclopedia of Fish Physiology: from Genome to Environment. pp. Elsevier

38. Ortiz Juan B, Gonzalez de Canales ML, Sarasquete C (2003) Histopatho- logical changes induced by lindane $(\mathrm{y}-\mathrm{HCH})$ in various organs of fish. Sci Mar 67:53-61

39. Paiva CN, Bozza MT (2014) Are Reactive Oxygen Species Always Detrimental to Pathogens? 20:1000-10376

40. Parry RM, Chandau RC, Shahani RM (1965)A rapid sensitive assay of muramidase

41. Proceedings of the Society for Experimental Biology and Medicine119: 384-386

42. Paulino MG, Benze TP, Sadauskas-Henrique H, Sakuragui MM, Fernandes JB, Fernandes MN (2014) The impact of organochlorines and metals on wild fish living in a tropical hydroelectric reservoir: bioaccumulation and histopathological biomarkers. Sci Total Environ 497-498:293-306 
43. Peters G, Schwarzer R (1985) Changes in haemopoietic tissueof rainbow trout under influenceof stress. Dis Aquat Organ 1:1-10

44. Pistl J, Kovalkovicova N, Holovska V, Legath J, Mikula I (2003) Determination of the immunotoxic potential of pesticides on functional activity of sheep leukocytes in vitro. Toxicology 188:73-81

45. Prusty AK, Kohli MPS, Sahu NP, Pal AK, Saharan N, Mohapatra S, Gupta SK (2011) Effect of shortterm exposure of fenvalerate on biochemical and haematological responses in Labeorohita (Hamilton) fingerlings. Pestic Biochem Physiol 100:124-129

46. Roy S, Chattoraj A, Bhattacharya S (2006) Arsenic-induced changes in optic tectal histoarchitecture acetylcholinesterase-acetylcholine profile in Channa punctatus: amelioration by selenium. Comput Biochem Physiol C 144:16-24

47. Sanchez-Vazquez FJ, Lopez-Olmeda JF, Migaud H, López-Patiño MA (2019) Míguez JM.. Environmental Cycles, Melatonin, and Circadian Control of Stress Response in Fish. Front Endocrinol (Lausanne). 10:279

48. Sancho E, Fernandez-Véga C, Sanchez M, Ferrando MD, Andreu-Moliner E (2000) Alterations on AChE activity of the fish Anguilla anguilla as response to herbicide- contaminated water. Ecotoxicol Environ Saf 46:57-63

49. Sankaran K, Gurnani S (1972) On the variation in the catalytic activity of lysozyme in fishes. Indian Journal of Biochemistry and Biophysics 9:162-165

50. Saurabh S, Sahoo PK (2008) Lysozyme: an important defence molecule of fish innate immune system. Aquac Res 39:223-239

51. Simonato JD, Guedes CLB, Martinez CBR (2008) Biochemical, physiological, and histological changes in the neotropical fish Prochiloduslineatus exposed to diesel oil. Ecotoxicol Environ Saf 69(1):112-120

52. Soltani M, Pourgholam R (2007) Lysozyme activity of grasscarp (Ctenopharingodon idella) following exposure to sublethal concentrations of organophosphate. diazinon Veterinary Research 62:50-52

53. Stevens J, Breckenridge C (2001) Crop protection chemicals.. In: In: Hayes WA (ed) Principles and Methods of Toxicology. Taylor \& Francis, Philadelphia, pp 718-816

54. Strzyżewska-Worotyńska E, Szarek J, Babińska I, Gulda D (2017) Gills as morphological biomarkers in extensive and intensive rainbow trout (Oncorhynchus mykiss, Walbaum 1792) production technologies. Environ Monit Assess 189:611

55. Sudova E, Piackova V, Kroupova H, Pijacek M, Svobodova Z (2009) The effect of praziquantel applied per os on selected haematological and biochemical indices in common carp (Cyprinus carpio L.). Fish Physiol Biochem 35:599-605

56. Tayeb W, Chaieb I, Hammami M (2011) Environmental fate and effects of 2,4- dichlorophenoxyacetic herbicide.. In: In: Piotrowsky KP (ed) Herbicides: Properties, Crop Protection and Environmental Hazards. Nova Sciences Publisher, NY, pp 161-187

57. Tayeb W, Nakbi A, Trabelsi M, Attia N, Miled A, Hammami M (2010) Hepatotoxicity induced by subacute exposure of rats to 2,4-dichlorophenoxyacetic acid based herbicide "Désormonelourd". J 
Hazard Mater 180:225-233

58. Ton C, Lin Y, Willett C (2006) Zebrafish as a model for developmental neurotoxicity testing. Birth defects research, part A. 76:553-567

59. Velmurugan B, Thresia Mathews T, Eliflpek C (2009) Histopathological effects of cypermethrin on gill, liver and kidney of fresh water fish Clariasgariepinus (Burchell, 1822), and recovery after exposure. Environ Technol 30(13):1453-1460

60. Vigario., Saboia-Morais. Effects of the 2,4-D herbicide on gills epithelia and liver of the fish Poecilia vivipara.Pesq.Vet. Bras.34(6):523-528

61. Wafa T, Ikbal C, Mohamed H (2011) Environmental fate and effects of 2,4-dischlorophenoxyacetic acid herbicide. In: Herbicides: Properties, pp. 245-262

62. Walton JC, Weil ZW, Nelson RJ (2011) Influence of Photoperiod on Hormones, Behavior, and Immune Function. Front Neuroendocrinol 32(3):303-319

63. World Health Organization (WHO) (1984) Environmental Health Criteria 29. IPCS International Programme on Chemical Safety, United Nations Environment Programme, International Labour Organisation, and the World Health Organization, pp 1-1512,4-Dichlorophenoxyacetic acid (2,4-D)

64. Zahran E, Risha E, Awadin W, Palic D (2018) Acute exposure to chlorpyrifos induces reversible changes in health parameters of Nile tilapia (Oreochromisniloticus). Aquat Toxicol 197:47-59

65. Zheng X, Zhang K, Zhao Y, Fent K (2021) Environmental chemicals affect circadian rhythms: An underexplored effect influencing health and fitness in animals and humans. Environ Int 149:106159

\section{Figures}




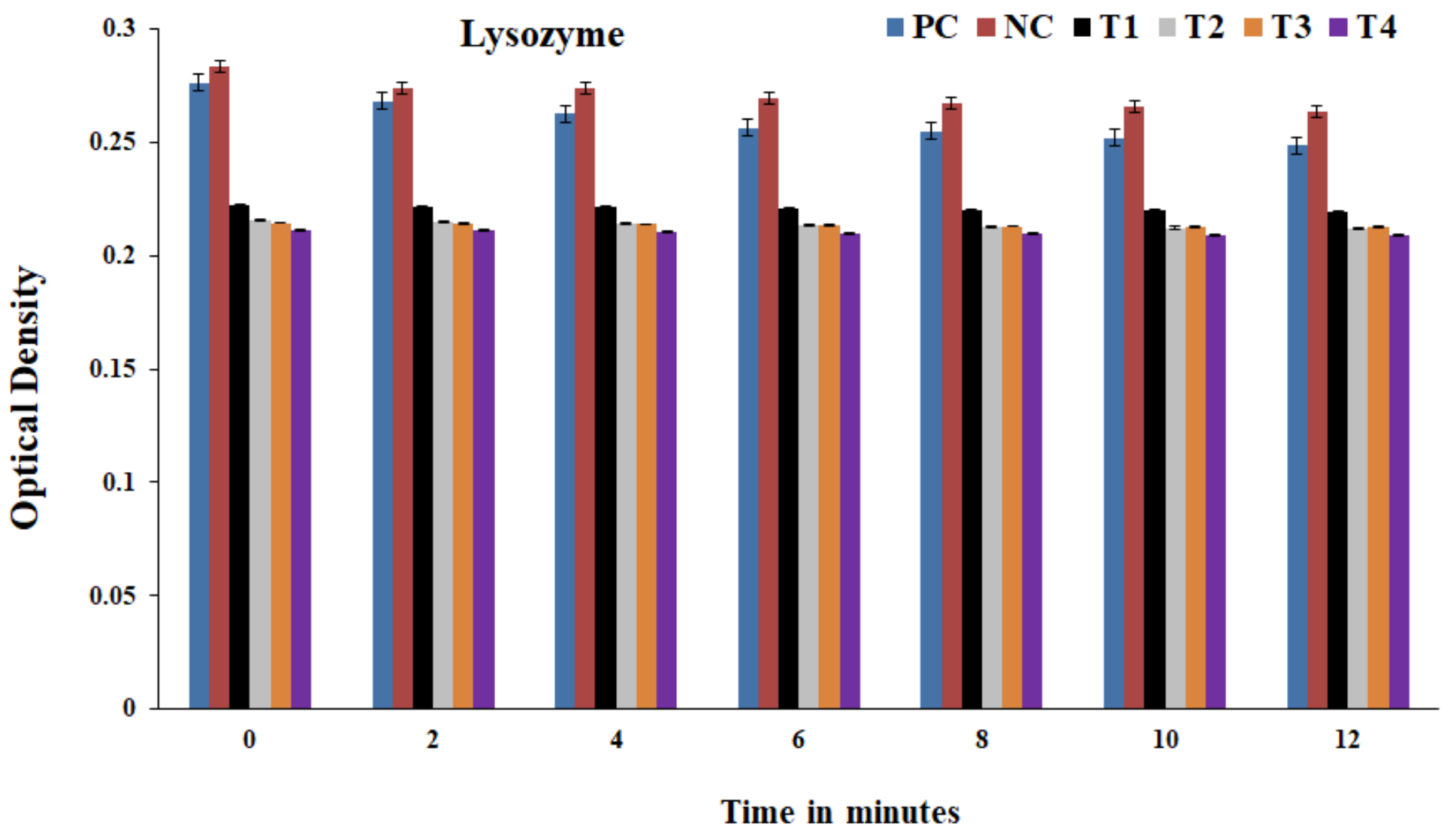

Figure 1

Lysozyme activity in the serum in common carp Cyprinus carpio exposed to herbicide 2,4-D 


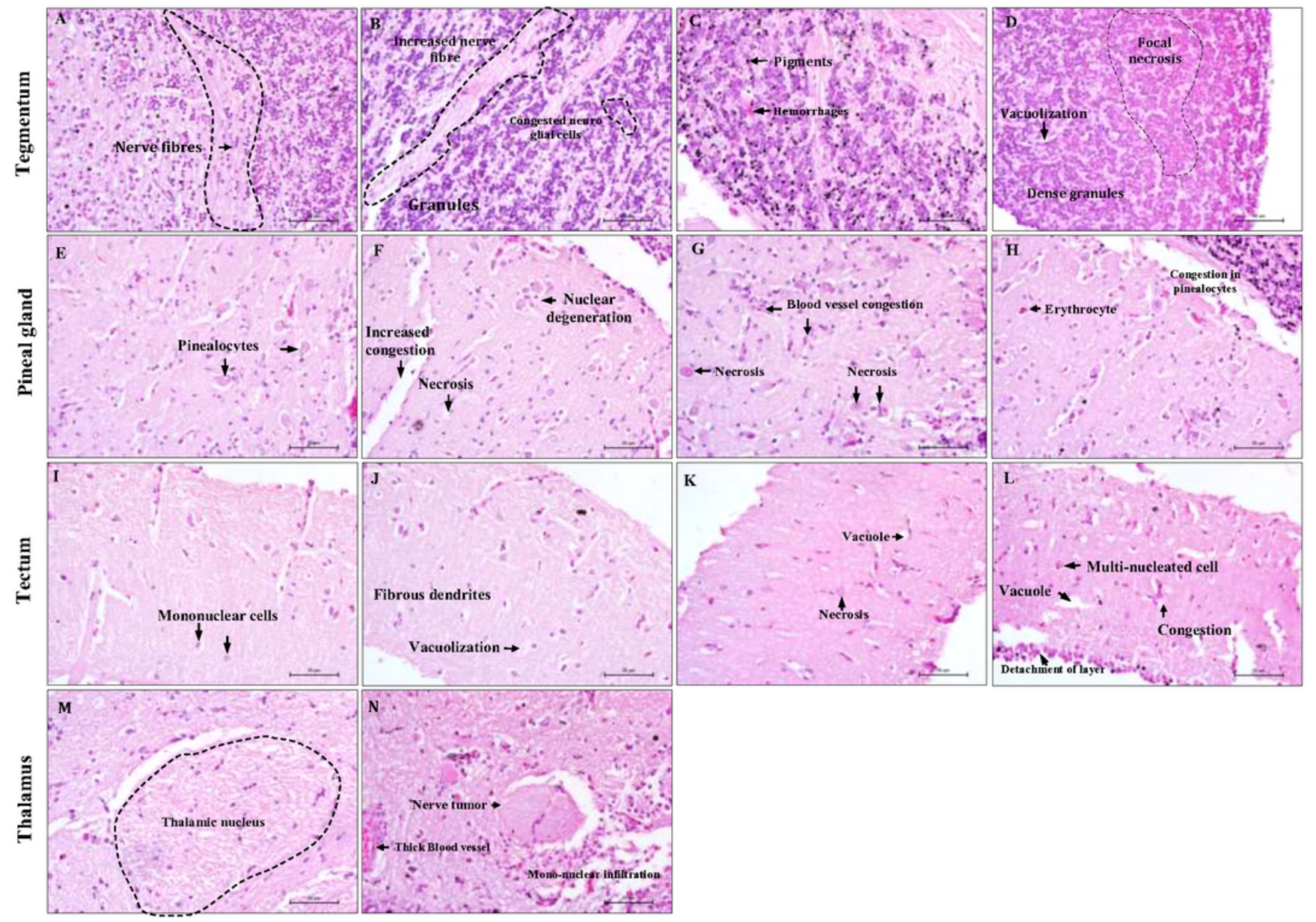

Figure 2

Microphotographs for detection of changes in the tegmentum (A-D), pineal gland (E-H), tectum (I-L) and thalamus $(M \& N)$ of the brain of common carp Cyprinus carpio. Control (A, E, I \& M), Fish exposed to 2.9 $\mathrm{mg} / \mathrm{L}$ 2,4-D (B, F, J), Fish exposed to $29 \mathrm{mg} / \mathrm{L}$ 2,4-D (C, G, K), Fish exposed to $58 \mathrm{mg} / \mathrm{L}$ 2,4-D (D, H, L \& N). Scale bar $=50 \mu \mathrm{m}$. H \& E staining.

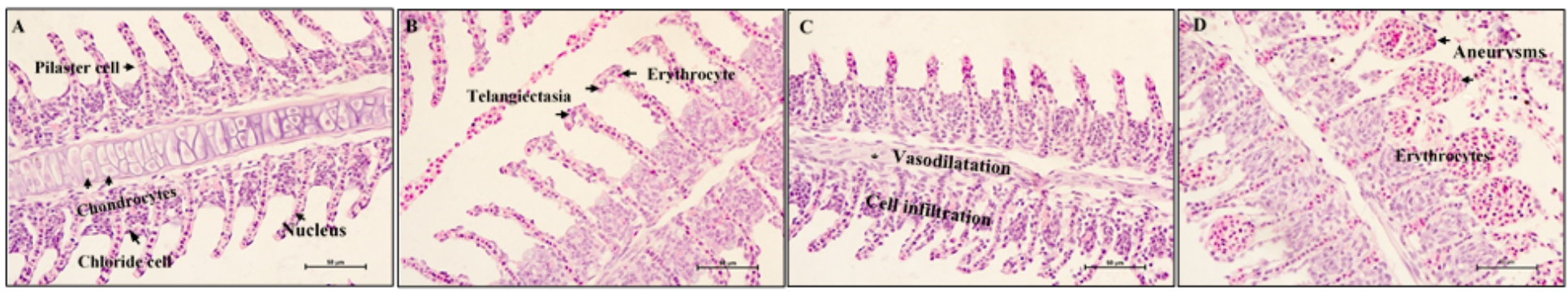

\section{Figure 3}


Microphotographs for detection of changes in the gills of common carp Cyprinus carpio. A) Control, B) Fish exposed to $2.9 \mathrm{mg} / \mathrm{L}$ 2,4-D, C) Fish exposed to $29 \mathrm{mg} / \mathrm{L}$ 2,4-D, C) Fish exposed to $58 \mathrm{mg} / \mathrm{L}$ of 2,4 D. Scale bar $=50 \mu \mathrm{m}$. H \& E staining.

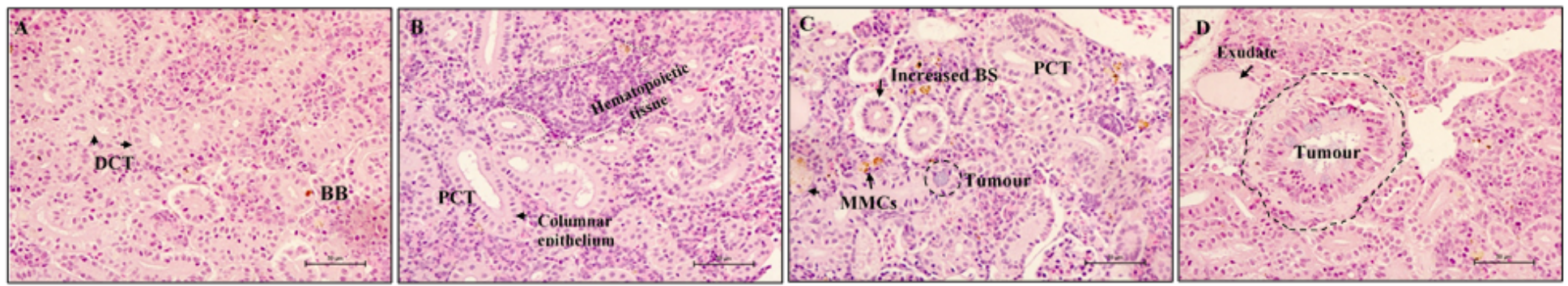

\section{Figure 4}

Microphotographs for detection of changes in the kidney of common carp Cyprinus carpio. A) Control, B) Fish to $2.9 \mathrm{mg} / \mathrm{L}$ 2,4-D, C) Fish exposed to $29 \mathrm{mg} / \mathrm{L} 2,4-D, C)$ Fish exposed to $58 \mathrm{mg} / \mathrm{L} 2,4-D$. Scale bar $=50 \mu \mathrm{m}$. H \& E staining. DCT: Distal convoluted tubules, PCT: Proximal Convoluted Tubules; BS: Bowman's space; BB: Brush border. Scale bar $=50 \mu \mathrm{m}$. H \& E staining.
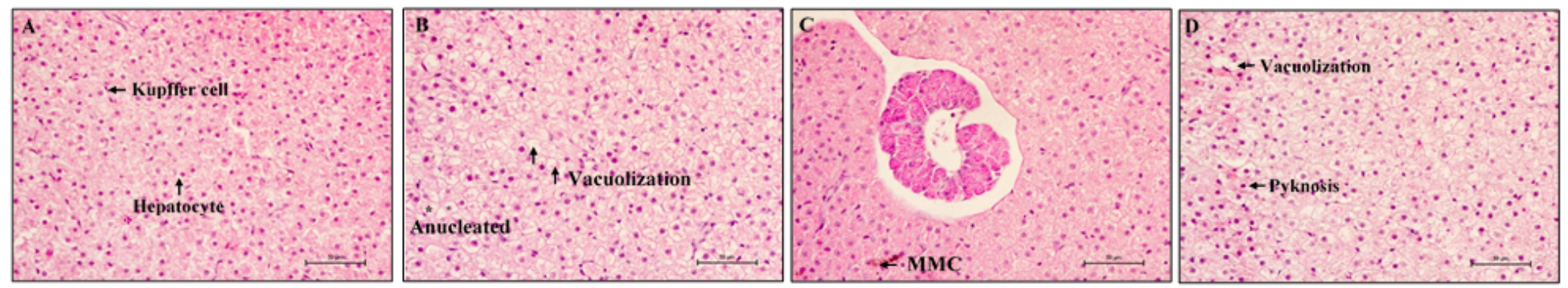

\section{Figure 5}

Microphotographs for detection of changes in the liver of common carp Cyprinus carpio. A) Control, B) Fish to $2.9 \mathrm{mg} / \mathrm{L}$ 2,4-D, C) Fish exposed to $29 \mathrm{mg} / \mathrm{L}$ 2,4-D, C) Fish exposed to $58 \mathrm{mg} / \mathrm{L}$ 2,4-D. Scale bar=50 $\mu \mathrm{m} . \mathrm{H} \&$ E staining. 